\title{
KELAYAKAN USAHA AGROWISATA DI KABUPATEN REMBANG
}

\author{
Achmat Bukhori1), dan Rita Nurmalina2) \\ 1,2)Departemen Agribisnis, Fakultas Ekonomi dan Manajemen, Institut Pertanian Bogor \\ Jl. Kamper Wing 4 Level 5 Kampus IPB Dramaga, Indonesia \\ e-mail: 1)bukhoriach21@gmail.com
}

(Diterima 14 Agustus 2020 / Revisi 27 Oktober 2020 / Disetujui 1 Desember 2020)

\begin{abstract}
Agrotourism is tourism that utilizes agricultural business as a tourism destination, with the purpose of recreation, increasing knowledge, and building business in agricultural. The purpose of this research is to analyze the investment feasibility of agrotourism. The location of the research was conducted in De Kampoeng Rembang Agrotuorism which is an agrotourism with the main commodity of dragon fruit and combined with edu-tourism. In this research will be compared to the feasibility business of agrotourism without restaurant facilities (scenario I) with agrotourism that adds restaurant facilities (scenario II). Feasibility of non-financial business was analyzed using the market aspects, technical aspects, management aspects, law aspects, social, economic, cultural aspects, and environmental aspects. Whereas feasibility of financial business was analyzed using the investment criteria, that covered NPV, Net B/C, IRR, and Payback Period, and also switching value analysis. The result shows that De Kampoeng Rembang Agrotourism is feasible based on non-financial aspects and financial aspects. The result of investment criteria analysis shows that the business of agrotourism with restaurant facilities have better performance than the business of agrotourism without restaurant facilities. While based on switching value analysis, the result shows that the decreasing in the number of visitors is more sensitive to business feasibility compared to the increasing in the salary of permanent workers on both scenarios.
\end{abstract}

Keywords: dragon fruit, feasibility of financial, feasibility of non-financial, restaurants, switching value

\begin{abstract}
ABSTRAK
Agrowisata merupakan pariwisata yang memanfaatkan usaha pertanian sebagai obyek wisata dengan tujuan untuk rekreasi, menambah pengetahuan, dan melakukan usaha di bidang pertanian. Tujuan dari penelitian ini adalah untuk menganalisis kelayakan investasi usaha agrowisata. Lokasi penelitian dilakukan di Agrowisata De Kampoeng Rembang yang merupakan agrowisata dengan komoditas utama buah naga yang dipadu dengan wisata edukasi. Dalam penelitian ini dibandingkan kelayakan usaha agrowisata tanpa fasilitas rumah makan (skenario I) dengan agrowisata yang menambah fasilitas rumah makan di dalamnya sebagai satu kesatuan (skenario II). Kelayakan non-finansial usaha dianalisis melalui aspek pasar, aspek teknis, aspek hukum, aspek manajemen, aspek sosial, ekonomi, dan budaya, serta aspek lingkungan. Kemudian kelayakan finansial usaha dianalisis menggunakan kriteria investasi meliputi NPV, Net B/C, IRR, dan Payback Period. Selain itu juga dilakukan analisis sensitivitas berdasarkan swicthing value. Hasil analisis yang diperoleh adalah usaha layak untuk dijalankan berdasarkan aspek non-finansial dan finansial. Hasil analisis kriteria investasi menunjukkan bahwa agrowisata dengan penambahan fasilitas rumah makan mempunyai performa yang lebih bagus dibanding dengan agrowisata tanpa penambahan fasilitas rumah makan. Sementara hasil analisis swicthimg value menunjukkan bahwa penurunan jumlah pengunjung lebih sensitif terhadap kelayakan usaha dibandingkan dengan kenaikan gaji tenaga kerja tetap pada kedua skenario.
\end{abstract}

Kata kunci: buah naga, kelayakan finansial, kelayakan non-finansial, rumah makan, swicthing value

\section{PENDAHULUAN}

Indonesia adalah sebuah negara yang dikaruniai kekayaan alam yang melimpah. Salah satu kekayaannya adalah pesona keindahan alamnya yang menjadi daya tarik bagi wisatawan.
Sektor pariwisata mempunyai potensi yang sangat besar bagi perekonomian negara. Data dari Kementerian Pariwisata tahun 2019 menunjukkan bahwa kontribusi sektor pariwisata terhadap PDB Indonesia dari tahun 2017-2019 selalu meningkat dengan rata-rata kontribusi sebesar 
4,47 \% per tahun. Selain itu berdasarkan data Kementerian Pariwisata tahun 2019, jumlah wisatawan di Indonesia dari tahun 2015-2018 juga meningkat.

Pengembangan sektor pariwisata dapat dilakukan melalui berbagai cara, salah satu caranya adalah melalui pengembangan agrowisata. Menurut Arifin (2001), agrowisata merupakan suatu bentuk kegiatan wisata yang dilakukan pada kawasan pertanian dengan aktivitas seperti persiapan lahan, penanaman, pemeliharaan, pemanenan, pengolahan hasil panen hingga menjadi barang jadi yang siap untuk dipasarkan dan dapat dibeli wisatawan sebagai oleh-oleh. Sementara itu, Malkanthi dan Routry (2004) menyatakan bahwa agrowisata merupakan pariwisata alternatif yang memanfaatkan usaha pertanian sebagai obyek wisata dengan tujuan untuk rekreasi, menambah pengetahuan, dan melakukan usaha di bidang pertanian. Agrowisata mempunyai peran sebagai media promosi dari produk-produk pertanian, serta sebagai sarana edukasi tentang pertanian.

Provinsi Jawa Tengah mempunyai potensi di bidang pertanian dan pariwisata, serta pengembangan agrowisata. Berdasarkan data Dinas Kebudayaan dan Pariwisata Provinsi Jawa Tengah tahun 2019 menunjukkan bahwa jumlah wisatawan yang berkunjung ke Jawa Tengah pada tahun 2014-2018 meningkat dengan rata-rata peningkatan per tahunnya sebesar 13,3 \%. Peningkatan jumlah wisatawan yang tinggi di Jawa Tengah terjadi di Kabupaten Rembang mencapai 198,5 \% dalam kurun waktu 5 tahun. Selain itu, Kabupaten Rembang mempunyai beberapa komoditas holtikultura yang berpotensi untuk pengembangan agrowisata. Salah satunya adalah komoditas buah naga yang dikembangkan di Kecamatan Rembang dan Pancur.

Buah naga sendiri merupakan buah non klimaterik atau hanya bisa matang dipohon saja, sehingga apabila dipanen sebelum waktunya akan menyebabkan penurunan kualitas buah. Selain itu petani buah naga organik di Kabupaten Rembang mengalami permasalahan dalam proses pemasaran produknya. Hal tersebut terjadi karena buah naga yang dibudidayakan secara organik mempunyai ukuran yang lebih kecil dibandingkan dengan non organik, sehingga pengepul tidak mau menerimanya. Salah satu alternatif solusi terkait dengan permasalahan tersebut adalah melalui pengembangan agrowisata dalam bentuk wisata petik buah naga.

Salah satu usaha budidaya buah naga di Kabupaten Rembang telah mengembangkan usahanya menjadi agrowisata petik buah naga. Usaha tersebut menawarkan produk barang dan jasa. Produk barangnya berupa buah naga organik dimana wisatawan dapat merasakan pengalaman memetik buah naga langsung dari pohonnya, sedangkan produk jasa yang ditawarkan berupa wisata edukasi terkait pertanian yang meliputi edukasi menaman, merawat, memetik buah naga, menanam sayur di lahan, menanam padi di sawah, cara berternak kelinci, dan mewarnai gambar tentang alam pada kertas yang telah disediakan. Melalui agrowisata yang dilengkapi wisata edukasi wisatawan mendapatkan pengetahuan dan wawasan terkait dunia pertanian, serta dapat berinteraksi dengan pengelola usaha.

Usaha agrowisata pada umumnya dilengkapi dengan berbagai fasilitas guna menunjang kegiatan para wisatawan. Salah satunya adalah fasilitas rumah makan. Adanya fasilitas rumah makan pada usaha agrowisata ditujukan sebagai pelengkap kegiatan para wisatawan yang berupa wisata kuliner. Menurut Besra dalam Sasongko et al. (2019) menyatakan bahwa wisata kuliner tidak seperti produk wisata bahari, budaya, dan alam yang dipasarkan sebagai produk wisata utama, tetapi pada wisata kuliner biasanya dipasarkan sebagai produk wisata penunjang.

Usaha agrowisata merupakan salah satu bentuk diversifikasi dari usaha di bidang pertanian dan bagian dari obyek wisata. Jenis usaha agrowisata yang dikembangkan di Kabupaten Rembang berbasiskan komoditas holtikultura. Harapan dari pengembanagn agrowisata pada komoditas holtikultura adalah mampu mengatasi permasalahan-permasalahan yang dialami petani holtikultura di Kabupaten Rembang. Selain itu usaha agrowisata merupakan. Permasalahan tersebut antara lain biaya produksi untuk pengadaan input seperti benih dan pupuk yang realtif tinggi (hulu), minimnya penggunaan teknologi dalam proses budidayanya yang menghambat kualitas dan produktivitas (on farm). Hal tersebut menyebabkan pendapatan petani holtikultura yang 
relatif rendah. Data dari BPS tahun 2018 menunjukkan bahwa nilai tukar petani holtikultura (NTP-H) dari tahun 2015-2018 di bawah angka 100 dan merupakan yang terendah dari lima subsektor yaitu tanaman pangan, tanaman perkebunan rakyat, pertenakan, perikanan, dan holtikultura. Tantangan selanjutnya adalah terkait dengan infrastuktur seperti tempat penyimpanan dan penjualan di pasar yang harganya sangat fluktuatif (hilir).

Tabel 1. Pertumbuhan Obyek Wisata di Kabupaten Rembang Tahun 20152019

\begin{tabular}{cc}
\hline Tahun & Jumlah Obyek Wisata (Unit) \\
\hline 2015 & 8 \\
2016 & 9 \\
2017 & 18 \\
2018 & 23 \\
2019 & 25 \\
\hline
\end{tabular}

Sumber: Dinas Kebudayaan dan Pariwisata Kabupaten Rembang 2019 (diolah)

Sementara itu sebagai bagian dari obeyk wisata, usaha agrowisata di Kabupaten Rembang akan tantangan di dunia pariwisata. Berdasarkan data pada Tabel 1, jumlah obyek wisata di Kabupaten Rembang selalu meningkat setiap tahun. Dalam periode 2015-2019 terjadi penambahan obyek wisata yang signifikan yaitu pada tahun 2015 hanya terdapat 8 obyek wisata dan pada tahun 2019 telah meningkat menjadi 25 obyek wisata. Sebagai jenis usaha yang baru dikembangkan, usaha agrowisata di Kabupaten Rembang akan menghadapi persaingan pasar yang cukup kompetitif karena jumlah pesaing di bidang pariwisata akan terus bertambah. Selain itu biaya investasi untuk pengadaan fasilitas usaha agrowisata di Kabupaten Rembang cukup besar, sehingga perlu dikaji apakah biaya investasi yang dikeluarkan akan memberikan manfaat yang lebih besar atau tidak. Berdasarkan permasalahan tersebut maka dibutuhkan analisis kelayakan usaha baik dari aspek non finansial maupun aspek finansial terhadap usaha agrowisata di Kabupaten Rembang (skenario I)

Usaha agrowisata di Kabupaten Rembang telah mempunyai beberapa fasilitas untuk menunjang kegiatan wisatawan seperti kebun buah naga, rumah kelinci, taman bunga, gazebo, toilet, dan tempat parkir. Salah satu fasilitas yang belum tersedia adalah rumah makan, sehingga permintaan komsumsi makan dan minum dari wisatawan belum bisa terpenuhi. Dalam penelitian Mahaputriana (2006), Nugroho (2010), dan Fikri (2012) menunjukkan bahwa usaha agrowisata yang diteliti telah dilengkapi dengan fasilitas rumah makan dan menjadi salah satu sumber pendapatan. Pada umumnya usaha pariwisata di Kabupaten Rembang juga telah dilengkapi dengan fasilitas rumah makan untuk memenuhi kebutuhan komsumsi wisatawannya. Oleh karena itu, adanya penambahan fasilitas rumah makan pada usaha agrowisata di Kabupaten Rembang diharapkan dapat memenuhi permintaan konsumsi dari wisatawan dan mampu meningkatkan pendapatan usaha. Disisi lain, penambahan fasilitas rumah makan akan memerlukan penambahan aset baru dan membutuhkan biaya investasi yang relatif besar. Berdasarkan hal tersebut diperlukan analisis kelayakan usaha pada usaha agrowisata di Kabupaten Rembang dengan penambahan fasilitas rumah makan (skenario II). Dalam menjalankan sebuah usaha akan dihadapkan pada ketidakpastian berupa perubahanperubahan variabel inflow maupun outflow yang berpengaruh besar terhadap kelayakan usaha agrowisata, sehingga akan dilakukan analisis sensitivitas menggunakan analisis swicthing value. Berdasarkan uraian di atas, maka tujuan dari penelitian ini adalah 1) menganalisis kelayakan aspek non-finansial usaha agrowisata di Kabupaten Rembang meliputi aspek pasar, teknis, manajemen, hukum, sosial, ekonomi, dan budaya, serta lingkungan, 2) menganalisis kelayakan aspek finansial usaha agrowisata di Kabupaten Rembang, 3) menganalisis tingkat sensitivitas usaha agrowisata di Kabupaten Rembang berdasarkan analisis swicthing value jika terjadi penurunan jumlah pengunjung dan kenaikan gaji tenaga kerja tetap

\section{METODE}

\section{LOKASI DAN WAKTU PENELITIAN}

Penelitian dilakukan di Agrowisata De Kampoeng Rembang yang terletak di Dukuh Sugihan, Desa Pulo, Kecamatan Rembang, Kabupaten Rembang, Jawa Tengah. Pemilihan lokasi penelitian dilakukan secara sengaja 
(purposive) dengan pertimbangan bahwa obyek agrowisata di Kabupaten Rembang sangat terbatas dan Agrowisata De Kampoeng Rembang merupakan satu-satunya usaha agrowisata yang sudah mampu menjalankan proses operasionalnya selama dua tahun. Sementara potensi agrowisata berbasiskan komoditas yang masih dalam tahap perencanaan. Penelitian di lapangan dilakukan pada bulan Januari-Februari 2020.

\section{METODE PENGOLAHAN DAN ANALISIS DATA}

Analisis data dalam penelitian ini dilakukan dengan dua cara yaitu secara kualitatif dan kuantitatif. Analisis data kualitatif digunakan untuk menganalisis kelayakan aspek non-finansial usaha agrowisata di Kabupaten Rembang meliputi aspek pasar, teknis, manajemen, hukum, sosial, ekonomi, dan budaya, serta lingkungan. Sementara itu, analisis data kuantitatif digunakan untuk menganalisis kelayakan aspek finansial usaha agrowisata di Kabupaten Rembang baik tanpa penambahan fasilitas rumah makan maupun dengan penambahan fasilitas rumah makan. Data kuantitatif diolah menggunakan Microsoft Excel 2013.

\section{ANALISIS KELAYAKAN NON-FINANSIAL}

Analisis kelayakan aspek non-finansial mengkaji kelayakan usaha dari berbagai aspek seperti yang telah dilakukan penelitian sebelumnya (Dewi dan Farmayanti 2011; Sumantri dan Farianti 2011; Nisa et al., 2014; Syaifullah 2018; Nabila dan Nurmalina 2019; Ramadhanty et al., 2020) yaitu aspek pasar, aspek teknis, aspek manajemen dan hukum, aspek sosial-ekonomibudaya, dan aspek lingkungan. Pada aspek pasar, variabel yang dianalisis meliputi permintaan, penawaran, harga, program pemasaran meliputi strategi pemasaran (segmentation, targetting, positioning) dan bauran pemasaran (marketing mix), serta penjualan industri dan perusahaan (market share). Pada aspek teknis, yang akan diteliti meliputi lokasi suatu bisnis, skala operasional dan luas produksi, layout atau tata letak, alur produksi, serta pemilihan jenis teknologi dan peralatan. Pada aspek manajemen hal yang diperhatikan adalah struktur organisasi, wewenang dan tanggung jawab, perolehan tenaga kerja, dan sistem penggajian tenaga kerja. Pada aspek hukum hal yang diperhatikan adalah bentuk badan hukum usaha dan izin usaha. Pada aspek sosial-ekonomi-budaya yang akan dinilai adalah dampak yang akan ditimbulkan dari usaha dari sisi sosial-ekonomi-budaya. Pada aspek lingkungan yang akan dinilai adalah dampak yang ditimbulkan dari usaha terhadap lingkungan.

\section{ANALISIS KELAYAKAN FINANSIAL}

Analisis kelayakan finansial dilakukan dengan menggunakan pendekatan kriteria investasi (Nurmalina et al., 2014), yaitu:

\section{Net Present Value (NPV)}

$$
N P V=\sum_{t=1}^{n} \frac{B t-C t}{(1+i)^{t}}
$$

Keterangan:

$\mathrm{NPV}=$ Net Present Value $(\mathrm{Rp})$

$\mathrm{Bt}=$ manfaat pada tahun ke-t

$\mathrm{Ct}$ = biaya pada tahun ke-t

$\mathrm{i} \quad=$ Discount rate $(4,5 \%)$

$\mathrm{t} \quad=$ tahun ke- $\mathrm{t}$

Indikator kelayakannya adalah : jika NPV bernilai positif (NPV>0) maka usaha layak untuk dijalankan. Sebaliknya, jika NPV bernilai negatif $(\mathrm{NPV}<0)$ maka usaha tidak layak untuk dijalankan.

\section{Net Benefit Cost Ratio (Net B/C)}

$$
\operatorname{Net} \frac{B}{C}=\frac{\frac{\sum_{t=1}^{n} B_{t}-C_{t}}{(1+i)^{t}}}{\frac{\sum_{t=1}^{n} B_{t}-C_{t}}{(1+i)^{t}}}=>\frac{\left[B_{t}-C_{t}\right]>0}{\left[B_{t}-C_{t}\right]<0}
$$

Keterangan:

$\mathrm{Bt}=$ manfaat pada tahun $\mathrm{t}$

$\mathrm{Ct}=$ biaya pada tahun $\mathrm{t}$

$\mathrm{n}=$ jumlah tahun

$\mathrm{i}=$ Discount rate $(4,5 \%)$

Penilaian kelayakan investasi berdasarkan nilai Net B/C adalah:

1) Net $B / C>1$, artinya adalah usaha tersebut layak (usaha menguntungkan)

2) Net $B / C=1$, artinya adalah usaha tidak mengalami keuntungan ataupun kerugian

3) Net $B / C<1$, artinya adalah usaha tersebut tidak layak (usaha merugikan) 
3. Internal Rate of Return (IRR)

$$
I R R=i_{1}+\frac{N P V_{1}}{\left(N P V_{1}-N P V_{2}\right)}\left(i_{2}-i_{1}\right)
$$

Keterangan :

$\mathrm{i} 1$ = Discount rate yang menghasilkan NPV positif

i2 = Discount rate yang menghasilkan NPV negatif

NPV1 = NPV yang bernilai positif

NPV2 = NPV yang bernilai negatif

Indikator kelayakannya adalah : jika IRR lebih besar dari discount rate yaitu sebesar 4,5\% (IRR $>$ DR) maka usaha layak untuk dijalankan. Sebaliknya jika IRR lebih kecil dari discount rate yaitu sebesar 4,5\% (IRR<DR) maka usaha tidak layak untuk dijalankan. Dalam penelitian ini digunakan discount rate berdasarkan suku bunga deposito bank yang digunakan yaitu Bank Mandiri

\section{Payback Period (PP)}

$$
P P=\frac{\mathrm{I}}{\mathrm{Ab}}
$$

Keterangan:

$\mathrm{I}$ = Biaya investasi yang diperlukan

$\mathrm{Ab}=$ Manfaat bersih yang diperoleh setiap tahunnya

Suatu usaha dikatakan layak apabila nilai PP lebih kecil dari umur usaha, dalam penelitian ini diasumsikan umur usaha adalah 15 tahun. Semakin cepat pengembalian biaya investasi suatu usaha, maka semakin baik untuk diusahakan.

\section{Analisis Swicthing Value}

Analisis switching value merupakan analisis sensitivitas yang digunakan untuk mengukur perubahan maksimum dari perubahan suatu komponen inflow atau outflow yang masih dapat ditoleransi agar bisnis masih dapat tetap layak untuk dijalankan (Nurmalina dan Sarianti, 2016)

$$
\text { Swicthing Value }=X_{1}+\frac{N P V_{1}}{\left(N P V_{1}-N P V_{2}\right)}\left(X_{2}-X_{1}\right)
$$

Keterangan:

$\mathrm{X} 1$ = Persentase perubahan yang menghasilkan nilai NPV positif

$\mathrm{X} 2$ = Persentase perubahan yang menghasilkan nilai NPV negatif
NPV1 = NPV yang bernilai positif

$\mathrm{NPV} 2$ = NPV yang bernilai negatif

\section{GAMBARAN UMUM LOKASI PENELITIAN}

Usaha Agrowisata De Kampoeng Rembang yang merupakan lokasi pengambilan data terletak di Dukuh Sugihan, Desa Pulo, Kecamatan Rembang, Kabupaten Rembang, Jawa Tengah. Lokasinya hanya berjarak 2,8 $\mathrm{km}$ dari pusat Kabupaten Rembang cukup strategis. Usaha ini membudidayakan komoditas buah naga sebagai komoditas utamanya. Selain itu usaha ini juga dilengkapi dengan fasilitas rumah kelinci, kebun sayur, lahan tanam padi dan fasilitas lainnya untuk menunjang operasionalnya. Output yang dihasilkan terdiri dari barang dan jasa. Output barang yang dihasilkan adalah buah naga organik, sedangkan output jasanya adalah wisata edukasi dan wisata alam. Wisata edukasi yang tersedia yaitu edukasi buah naga, edukasi beternak kelinci, edukasi tanam padi, edukasi tanam sayur, dan edukasi mewarnai. Kegiatan edukasi buah naga meliputi praktik penanaman buah naga dalam polybag, kemudian cara pemeliharaan buah naga, dan wisatawan bisa melakukan pemetikan buah naga. Kemudian kegiatan edukasi kelinci meliputi cara beternak, memelihara, dan memberi makan kelinci. Kegiatan edukasi tanam padi dilakukan di sawah dan bibit padi telah disiapkan. Kemudian kegiatan tanam sayur dilakukan di lahan yang telah dibuat bedengan, sayur yang biasa ditanam adalah bayam, kangkung, terong, dan cabai. Sementara itu kegiatan edukasi mewarnai gambar di alam berupa lomba mewarnai gambar tentang alam pada kertas yang telah disediakan oleh pihak pengelola agrowisata

\section{HASIL DAN PEMBAHASAN}

\section{ASPEK NON FINANSIAL}

\section{Aspek Pasar}

Kelayakan aspek pasar dinilai menggunakan beberapa kriteria, menurut Nisa et al, (2014) menyatakan bahwa aspek pasar suatu usaha dikatakan layak apabila usaha tersebut mempunyai potensi dan pangsa pasar yang jelas, bauran pemasaran yang dijalankan dengan baik, dan serta produk yang dihasilkan dapat diterima oleh pasar dan menguntungkan. Market potential atau po- 
tensi pasar usaha agrowisata di Kabupaten Rembang adalah wisatawan yang berkunjung ke Kabupaten Rembang. Dalam periode 5 tahun terakhir jumlah wisatawan di Kabupaten Rembang terus meningkat dengan rata-rata peningkatan per tahunnya mencapai 33,79\%. Berdasarkan data dari Dinas Kebudayaan dan Pariwisata Kabupaten Rembang tahun 2019 tentang jumlah wisatawan yang berkunjung ke Kabupaten Rembang tahun 2015-2019 yang dapat dilihat pada Tabel 2. Peningkatan jumlah wisatawan tersebut menunjukkan bahwa market potential usaha agrowisata di Kabupaten Rembang terus tumbuh.

Tabel 2. Jumlah Wisatawan yang Berkunjung ke Kabupaten Rembang 2015-2019

\begin{tabular}{ccc}
\hline Tahun & $\begin{array}{c}\text { Jumlah } \\
\text { (jiwa) }\end{array}$ & $\begin{array}{c}\text { Pertumbuhan } \\
\text { Pengunjung (\%) }\end{array}$ \\
\hline 2015 & 707.460 & \\
2016 & 1.270 .268 & 79,55 \\
2017 & 1.460 .808 & 15,00 \\
2018 & 1.810 .369 & 23,93 \\
2019 & 2.112 .298 & 16,68 \\
\hline \multicolumn{2}{l}{ Sumber: Disbudpar Rembang 2019 (diolah) }
\end{tabular}

Kemudian berdasarkan data dari Badan Pusat Statistik Kabupaten Rembang tahun 2019 terkait rata-rata pengeluaran untuk konsumsi menunjukkan bahwa dari 14 kelompok makanan, pengeluaran untuk konsumsi buah di Kabupaten Rembang menempati peringkat ke- 6 yaitu sebesar $5,12 \%$. Data tersebut menunjukkan bahwa market potential untuk produk buah-buahan di Kabupaten Rembamg termasuk buah naga mempunyai prospek yang bagus. Sementara itu produk buah naga yang dihasilkan usaha agrowisata di Kabupaten Rembang selalu habis terjual oleh para wisatawan.

Market share atau pangsa pasar usaha agrowisata di Kabupaten Rembang dihitung dengan cara membagi jumlah wisatawan yang berkunjung pada usaha agowisata dengan jumlah total wisatawan di Kabupaten Rembang (market potential). Tercatat berdasarkan data Dinas Kebudayaan dan Pariwisata Kabupaten Rembang per tahun 2019 terdapat 2.112.298 wisatawan yang berkunjung di Kabupaten Rembang. Sedangkan jumlah wisatawan yang berkunjung ke usaha agrowisata di Kabupaten Rembang per tahun 2019 sebanyak 32.960 jiwa. Maka market share yang diperoleh usaha agrowisata adalah sebesar (32.960/2.112.298) x $100 \%=1,56 \%$. Hasil tersebut menunjukkan bahwa usaha agrowisata baru mampu mencukupi 1,56 \% permintaan wisata di Kabupaten Rembang.

Segmentasi usaha agrowisata di Kabupaten Rembang dikelompokkan berdasarkan tiga variabel yaitu variabel geografis, demografis, dan psikologis. Variabel geografis membagi segmentasi pasar usaha agrowisata berdasarkan asal daerah wisatawan. Kemudian variabel demografis membaginya berdasarkan tingkat pendidikan dan tingkat pendapatan wisatawan. Sedangkan variabel psikologis membaginya berdasarkan status kehadiran dan gaya hidup. Berdasarkan segmentasi tersebut diperoleh target pasar dari usaha agrowisata di Kabupaten Rembang, Target pasarnya adalah masyarakat di Kabupaten Rembang, kemudian masyarakat dengan pendapatan menengah ke bawah hingga menengah ke atas, anakanak PAUD, TK, dan SD, dan wisatawan yang datang berkelompok, serta wisatawan yang tertarik untuk belajar pertanian dan memerhatikan lingkungan. Sedangkan positioning-nya adalah menjadi obyek wisata di Kabupaten Rembang yang mampu memberikan edukasi dan pengetahuan tentang pertanian, serta menjadi sarana rekreasi bagi wisatawan.

Produk yang disediakan terdiri dari barang dan jasa. Sucipto (2011) menyatakan bahwa proses penetapan harga dipengaruhi oleh dua faktor yaitu faktor internal dan faktor eksternal. Faktor internal adalah penetapan harga berdasarkan sasaran pemasaran, sedangkan faktor eksternal adalah penetapan harga berdasarkan pasar (permintaan konsumen dan harga kompetitor) dan kondisi ekonomi seperti tingkat inflasi, biaya bunga, resesi, dan kebijakan pemerintah. Usaha agrowisata di Kabupaten Rembang menetapkan harga berdasarkan pasar sasarannya, biaya produksi, dan harga kompetitor. Kemudian untuk distribusi produknya dilakukan secara langsung dari produsen ke konsumen (tanpa perantara) dan untuk kegiatan promosi dilakukan dengan beberapa cara meliputi media sosial, promosi online melalui whatsapp ke sekolah-sekolah, menjalin kerjasama dengan instansi pemerin- 
tahan, siaran di radio, dan mengikuti kegiatan pameran. Hasil analisis aspek pasar pada usaha agrowisata di Kabupaten Rembang secara umum dapat dinyatakan layak, dengan catatan perlu adanya upaya untuk meningkatkan market share usaha.

\section{Aspek Teknis}

Penilaian kelayakan pada aspek teknis didasarkan pada beberapa hal. Pertama, pemilihan lokasi bisnis. Kabupaten Rembang mempunyai luas wilayah sebesar 101,408 \% yang terdiri dari 67,04 \% lahan pertanian dan 31,96 \% lahan bukan pertanian. Ketersediaan lahan pertanian yang masih luas menjadi satu alasan untuk mengembangkan agrowisata di Kabupaten Rembang. Selain itu usaha agrowisata di Kabupaten Rembang dapat dikembangkan pada daerah perkotaan maupun pedesaan yang didukung dengan posisi strategis Kabupaten Rembang yang dilalui jalur pantura dan jalur alternatif, sehingga mudah untuk dijangkau oleh wisatawan. Hal tersebut didukung oleh sasaran pokok dari Rencana Pembangunan Jangka Panjang (RPJP) Kabupaten Rembang yaitu terwujudnya infrastruktur yang memadai dimana salah satu poinnya adalah Kemudian ketersedian bahan baku yang dibutuhkan untuk kegiatan operasional usaha agrowisata tersedia dengan baik di Kabupaten Rembang, meskipun ada bahan baku yang harus didatangkan dari luar daerah seperti bibit buah naga yang didatangkan dari Banyuwangi, karena merupakan jenis komoditas baru di Kabuapten Rembang. Ketersediaan sumber air di-supply dari sumur bor, sedangkan sumber listrik menggunakan PLN, sehingga terjamin ketersediaannya. Selanjutnya kebutuhan tenaga kerja untuk usaha agrowisata masih tersedia. Berdasarkan data BPS Kabupaten Rembang tahun 2019 terdapat 330.449 orang yang masuk dalam angkatan kerja, 96,3 \% telah bekerja dan 3,7 \% pengangguran. Kedua, skala dan fasilitas usaha. Skala usaha dari agrowisata di Kabupaten Rembang relatif masih kecil dan tidak terlalu besar, karena merupakan usaha jenis usaha baru sehingga masih dalam tahap pengembangan. Sementara itu usaha agrowisata harus dilengkapi dengan fasilitas penunjang. Berdasarkan hal tersebut usaha agrowisata di Kabupaten Rembang telah mempunyai fasilitas penunjang usaha yang meliputi loket, tempat parkir, mushola, toilet, dan fasilitas penambah daya tarik lain seperti adanya taman bunga, gazebo, serta spot foto. Ketiga adalah proses produksi. Proses produksi usaha agrowisata dibagi menjadi dua yaitu produksi jasa dan produksi barang. Proses produksi jasa dimulai dengan tahap persiapan bahan dan alat, kemudian pemesanan paket edukasi dari wisatawan, dan selanjutnya adalah proses edukasi yang didampingi pemandu. Sedangkan proses produksi barang sesuai dengan komoditas yang dibudidayakan. Secara umum tahapannya dimulai dari tahap persiapan lahan, persiapan bibit, penanaman, pemupukan dan perawatan, serta pemanenan dan pasca panen. Keempat adalah tata letak, usaha agrowisata di Kabupaten Rembang telah mengatur layout usaha untuk memudahakan kegiatan operasionalnya. Penataan layout usaha sendiri telah sesuai dengan Rencana Tata Ruang Wilayah (RTRW) Kabupaten Rembang yang menitikberatkan pada pemanfaatan ruang yang sesuai dengan peruntukannya. Kelima adalah penggunaan teknologi. Teknologi yang digunakan pada usaha agrowisata di Kabupaten Rembang adalah teknologi-teknologi yang berkaitan dengan proses usaha pertanian seperti sprayer, alat pemotong rumput, dan peralatan lainnya, serta teknik budidaya yang yaitu teknik budidaya organik. Berdasarkan hasil analisis aspek teknis di atas, dapat dinyatakan bahwa usaha agrowisata di Kabupaten Rembang layak untuk dijalankan.

\section{Aspek Hukum}

Penilaian aspek hukum dilihat dari bentuk badan usaha dan izin badan usaha. Bentuk badan usaha dari agrowisata di Kabupaten Rembang adalah perorangan, sehingga tanggung jawab sepenuhnya ditanggung secara pribadi oleh pemilik usaha. Kemudian terkait perizinan usaha, usaha agrowisata di Kabupaten Rembang telah menggantongi izin usaha seperti Tanda Daftar Usaha Pariwisata dengan nomor induk berusaha (NIB) salah satu usaha agrowisata adalah 9120202242789, serta juga telah mempunyai sertifikat izin mendirikan bangunan (IMB) berdasarkan keputusan Bupati Kabupaten Rembang dengan nomor SK-IMB-331710-11062019-01. Berdasarkan hasil analisis aspek hukum di atas 
dapat dinyatakan bahwa usaha agrowisata di Kabupaten Rembang layak untuk dijalankan.

\section{Aspek Manajemen}

Usaha agrowisata di Kabupaten Rembang telah mempunyai struktur organisasi usaha lengkap dengan pembagian tugas serta tanggung jawab. Berikut merupakan gambaran umum dari struktur organisasi usaha agrowisata di Kabupaten Rembang yang dapat dilihat pada Gambar 1.

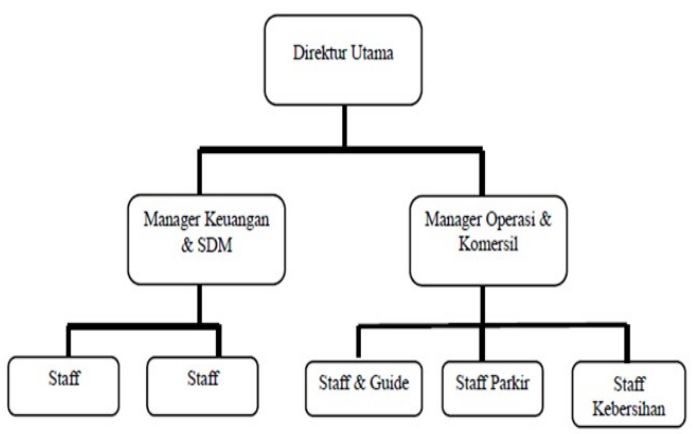

Gambar 1. Struktur Organsasi Usaha Agrowisata

Terdapat dua jenis tenaga kerja yang digunakan pada usaha ini yaitu tenaga kerja tetap dan tidak tetap, sehingga terdapat dua jenis sistem pembayaran tenaga kerja. Sistem pembayaran tenaga kerja tetap menggunakan sistem gaji per bulan yang besarnya sesuai dengan jabatan dan tanggung jawab. Sementara tenaga kerja digunakan ketika pada proses tertentu yang dan hanya dilakukan beberapa kali dalam satu tahun. Sistem pembayarannya menggunakan sistem upah yang artinya hanya dibayar jika ada pekerjaan saja. Berdasarkan hasil analisis aspek manajemen di atas dapat dinyatakan bahwa usaha agrowisata di Kabupaten Rembang layak untuk dijalankan

\section{Aspek Sosial, Ekonomi, dan Budaya}

Penilaian aspek sosial, ekonomi, dan budaya dilihat dari dampak yang diberikan usaha terhadap ketiga hal tersebut. Dampak positif secara sosial yang diberikan oleh usaha agrowisata di Kabupaten Rembang adalah terciptanya lingkungan yang aman di sekitar lokasi usaha agrowisata, serta memberikan efek ganda berupa terciptanya pembangunan akses menuju lokasi usaha. Selain itu wisatawan dapat menggunakan lokasi usaha untuk acara reuni, arisan, dan pameran. Kemudian dampak positif secara ekonomi yang diberikan dengan adanya usaha agrowisata di Kabupaten Rembang adalah mampu membuka peluang sumber pendapatan baru bagi masyarakat sekitar yaitu masyarakat yang bekerja di usaha agrowisata, serta para pelaku usaha di bidang pertanian. Selain itu bagi pemerintah daerah adanya usaha agrowisata menjadi salah satu penyumbang pendapatan daerah melalui pajak penghasilan yang dibayarkan. Berdasarkan data Badan Pusat Statistik 2018, sektor pertamian memberikan kontribusi $27 \%$ terhadap perekonomian daerah. Selanjutnya dalam hal budaya adanya usaha agrowisata di Kabupaten Rembang tidak bertentangan dengan norma dan adat istiadat yang berlaku. Wisatawan sangat mendukung adanya usaha agrowisata yang mampu memberikan edukasi tentang pertanian terutama kepada anak-anak, serta teknik budidaya organik yang dilakukan memberikan pengetahuan bagi masyarakat akan buah yang sehat untuk dikonsumsi. Berdasarkan hasil analisis aspek sosial, ekonomi, dan budaya di atas dapat dinyatakan bahwa usaha agrowisata di Kabupaten Rembang layak untuk dijalankan

\section{Aspek Lingkungan}

Dalam hal aspek lingkungan usaha agrowisata tidak menimbulkan dampak negatif terhadap lingkungan. Hal tersebut dikarenakan dengan adanya usaha agrowisata di Kabupaten Rembang mampu mengubah lahan menjadi hijau dan asri, sehingga kualitas udara menjadi baik. Selain itu adanya pemanfaatan dari limbah yang dihasilkan. Sebagai contohnya adalah pemanfaatan kotoran kelinci sebagai pupuk kandang. Selain itu teknik budidaya yang ramah lingkungan juga digunakan seperti sistem budidaya organik yang mampu menjaga kondisi tanah dari pencemaran zat-zat kimia yang berbahaya. Berdasarkan hasil analisis aspek lingkungan di atas dapat dinyatakan bahwa usaha agrowisata di Kabupaten Rembang layak untuk dijalankan. 


\section{ASPEK FINANSIAL}

\section{Analisis Kelayakan Finansial Skenario I (Agrowisata dengan produk buah naga dan jasa edukasi) dan Skenario II (Agrowisata dengan panambahan fasilitas rumah makan)}

Analisis finasial dilakukan menggunakan dua skenario. Skenario I merupakan kondisi usaha agrowisata tanpa penambahan fasilitas rumah makan, sedangkan skenario II merupakan usaha agrowisata dengan panambahan fasilitas rumah makan. Selanjutnya dilakukan analisis sensitivitas menggunakan swicthing value pada masingmasing skenario untuk melihat sensitivitas masing-masing skenario terhadap perubahanperubahan yang terjadi.

\section{Arus Penerimaan (Inflow)}

Sumber arus penerimaan utama usaha agrowisata pada skenario I terdiri dari dua komponen, yaitu penerimaan dari penjualan paket wisata dan penerimaan dari penjualan buah naga. Selain itu terdapat juga penerimaan nilai sisa dari aset di akhir umur usaha. Penerimaan dari penjualan paket wisata pada tahun $1 \& 2$ didapatkan dari referensi data penerimaan usaha agrowisata selama beroperasi. Kemudian untuk tahun ketiga didapatkan dari target penerimaan yang ingin dicapai, dan untuk tahun selanjutnya diasumsikan penerimaan naik $10 \%$ dari tahun sebelumnya. Hal tersebut didasarkan pada data pertumbuhan jumlah wisatawan di Kabupaten Rembang. Penerimaan dari penjualan buah naga didapatkan dari jumlah produksi dalam satu tahun dikalikan dengan harga jual yaitu Rp $15.000 / \mathrm{kg}$

Sementara itu, usaha agrowisata pada skenario II mempunyai tiga komponen arus penerimaan. Ketiga komponen tersebut meliputi penerimaan yang bersumber dari penjualan paket wisata, penerimaan dari penjualan buah naga, dan penerimaan dari penjualan produk rumah makan. Komponen penerimaan pada penjualan paket wisata dan produk buah naga diasumsikan sama dengan pada kondisi skenario I. Kemudian komponen penerimaan dari penjualan produk rumah makan dihasilkan dari jumlah produk terjual dikalikan dengan harganya.

\section{Arus Pengeluaran}

Sumber arus pengeluaran terdiri dari empat komponen yaitu biaya investasi, biaya operasional yang terdiri dari biaya operasional tetap dan variabel, biaya pajak, serta biaya lainlain. Investasi yang diperlukan untuk usaha agrowisata ditentukan oleh jenis agrowisata yang dikembangkan dan skala usaha. Kabupaten Rembang mengembangkan agrowisata berbasiskan komoditas holtikultura dengan skala usaha yang relatif kecil yaitu perorangan atau kelompok yang dikelola oleh desa. Biaya investasi utama yang dibutuhkan usaha agrowisata di Kabupaten Rembang antara lain adalah lahan untuk budidaya, komoditas yang akan dibudidayakan, fasilitas penunjang seperti loket, tempat parkir, toilet, dan mushola, serta fasilitas pelengkap seprti spot foto. Biaya investasi yang dibutuhkan pada skenario I digunakan untuk membeli peralatan dan perlengkapan, serta pembangunan untuk usaha agrowisata. Total biaya investasi yang dikeluarkan pada skenario I sebesar Rp 3.855.654.000. Sementara itu biaya investasi yang dikeluarkan pada skenario II lebih besar dibanding skenario I. Hal tersebut dikarenakan adanya penambahan biaya investasi untuk fasilitas rumah makan, sehingga total biaya investasi pada skenario II adalah sebesar Rp 3.959.699 000. Kemudian terdapat beberapa aset yang memerlukan reinvestasi.

Komponen arus pengeluaran yang selanjutnya adalah biaya operasional. Biaya operasional yang pertama adalah biaya tetap. Biaya tetap pada skenario I terdiri dari biaya gaji tenaga kerja tetap, listrik dan air, promosi, pemeliharaan kelinci dan tanaman, transportasi, keperluan kebersihan, serta alat tulis dan lainnya. Total biaya tetap yang dikeluarkan setiap tahun adalah sebesar Rp 159.000.000. Sedangkan total biaya tetap yang dikeluarkan pada skenario II setiap tahunnya adalah sebesar Rp 223.200.000. Biaya operasional yang selanjutnya adalah biaya variabel. Biaya variabel adalah biaya yang besarnya tergantung pada jumlah output yang dihasilkan, semakin besar output maka biaya variabel yang dikeluarkan juga semakin besar, dan begitu juga sebaliknya. Biaya variabel pada skenario I terdiri dari biaya variabel untuk paket wisata dan biaya variabel untuk budidaya buah naga. Sementara 
biaya variabel pada skenario II terdiri dari variabel untuk paket wisata, biaya variabel untuk budidaya buah naga, dan biaya variabel untuk produk rumah makan. Biaya variabel untuk paket wisata terdiri dari biaya variabel edukasi kelinci, edukasi tanam padi, edukasi tanam sayur, edukasi buah naga, dan edukasi mewarnai gambar di alam. Sedangkan biaya variabel untuk budidaya buah naga terdiri dari biaya untuk pupuk dan upah tenaga kerja tidak tetap. Sementara biaya variabel produk rumah makan terdiri dari biaya variabel untuk menu makanan yang terdiri dari bakso, mie ayam, nasi pecel, nasi soto, ayam goreng dan nasi, sedangkan untuk menu minuman terdiri dari es kelapa muda, es teh, es jeruk, dan jus buah naga.

Komponen arus pengeluaran yang selanjutnya adalah biaya pajak penghasilan. Biaya pajak yang dibebankan kepada usaha agrowisata didasarkan pada Peraturan pemerintah Republik Indonesia Nomor 23 Tahun 2018 yang menyatakan bahwa usaha yang memiliki pendapatan kotor di bawah 4,8 milyar maka dikenakan pajak sebesar 0,5 \% dari pendapatan sebelum pajak. Sedangkan komponen arus pengeluaran yang terakhir adalah biaya lain-lain yang terdiri dari biaya pembuatan Izin Mendirikan Bangunan (IMB) dan biaya pajak bumi dan bangunan.

\section{Hasil Analisis Kelayakan Skenario I dan Skenario II}

Laporan proyeksi laba rugi dapat digunakan untuk mengetahui perkembangan usaha ke depan dengan melihat hasil laba bersih yang diterima setiap tahun. Analisis laba rugi usaha agrowisata diperoleh dengan cara mengurangi komponen arus penerimaan dengan komponen biaya operasional yang terdiri dari biaya tetap dan biaya variabel. Laba kotor yang dihasilkan akan dikurangi biaya bunga sebesar 4,5 \%, karena modal yang digunakan adalah modal pribadi sehingga tidak ada biaya bunga yang dikeluarkan.
Laba sebelum pajak akan dikurangi dengan biaya pajak yang akan menghasilkan laba bersih. Biaya pajak penghasilan yang ditanggung adalah sebesar 0,5 \% dari pendapatan sebelum pajak. Hasil proyeksi laba rugi usaha pada skenario I dan skenario II mulai dari tahun ke 1 hingga 15 selalu positif dan mempunyai trend yang meningkat.

Selanjutnya adalah hasil analisis kelayakan finansial berdasarkan kriteria investasi. Kriteria investasi yang digunakan untuk menilai kelayakan finansial pada penelitian ini adalah Net Present Value (NPV), Net Benefit Cost Ratio (Net B/C), Internal Rate of Return (IRR), dan Payback Period (PP). Penelitian ini dilakukan dengan menggunakan bunga deposito Bank Mandiri sebagai discount rate yaitu sebesar 4,5\%. Hasil analisis kriteria investasi skenario I dan skenario II dapat dilihat pada Tabel 3.

Berdasarkan perhitungan pada Tabel 3, diperoleh nilai NPV pada skenario I sebesar Rp 2.491.366.015 dan pada skenario II sebesar Rp 7.170.972.910. Artinya usaha agrowisata tanpa penambahan fasilitas rumah makan menghasilkan manfaat bersih saat ini sebesar Rp 2.491.366.015 dan dengan penambahan fasilitas rumah makan akan menghasilkan manfaat bersih saat ini sebesar Rp 7.170.972.910 dalam jangka waktu 15 tahun. Kedua nilai tersebut lebih besar dari 0 , sehingga berdasarkan kriteria NPV, usaha agrowisata tanpa dan dengan penambahan fasilitas rumah makan layak untuk dijalankan.

Perhitungkan nilai Net B/C yang diperoleh pada skenario I sebesar 1,64, sedangkan pada skenario II sebesar 2,8. Artinya setiap Rp 1 biaya yang dikeluarkan usaha agrowisata tanpa penambahan fasilitas rumah makan akan memberikan manfaat bersih sebesar Rp 1,64, sedangkan dengan penambahan fasilitas rumah makan setiap Rp 1 biayanya akan memberikan manfaat bersih sebesar 2,8 satuan. Kedua nilai tersebut lebih besar dari satu, sehingga usaha agrowisata di

Tabel 3. Nilai NPV, Net B/C, IRR, dan Payback Period Skenario I dan Skenario II

\begin{tabular}{lrrr}
\hline \multicolumn{1}{c}{$\begin{array}{c}\text { Kriteria } \\
\text { Investasi }\end{array}$} & \multicolumn{1}{c}{ Skenario I } & Skenario II & Indikator \\
\hline NPV (Rp) & 2.491 .366 .015 & 7.170 .972 .910 & Lebih besar dari 0 \\
Net B/C & 1,64 & 2,8 & Lebih besar dari 1 \\
IRR (\%) & 9,57 & 17,17 & Lebih besar dari DR (4,5 \%) \\
PP & 10 tahun 9 bulan & 7 tahun 2 bulan & Kurang dari umur bisnis (15 tahun) \\
\hline
\end{tabular}


Kabupaten Rembang pada kedua kondisi tersebut layak untuk dijalankan.

Sementara itu, Nilai IRR yang diperoleh pada skenario I adalah sebesar 9,57 \% dan pada skenario II adalah sebesar 17,17 \%. Persentase IRR menunjukkan seberapa besar pengembalian bisnis terhadap investasi yang ditanamkan. Kedua nilai tersebut lebih besar dari discount rate yang digunakan yaitu sebesar 4,5\%, sehingga usaha agrowisata di Kabupaten Rembang tanpa dan dengan penambahan fasilitas rumah makan layak untuk dijalankan.

Lama payback period (PP) dari usaha ini pada skenario I adalah selama 10 tahun 9 bulan dan pada skenario II adalah selama 7 tahun 2 bulan. Payback period pada kedua skenario mempunyai periode yang lebih cepat dari umur bisnis usaha yaitu 15 tahun, sehingga usaha agrowisata di Kabupaten Rembang layak untuk dijalankan baik tanpa penambahan maupun dengan penambahan fasilitas rumah makan.

\section{Analisis Switching Value}

Analisis swicthing value merupakan analisis sensitivitas yang digunakan untuk mengetahui batas perubahan maksimum dari komponenkomponen inflow maupun outflow yang berpengaruh penting bagi bisnis sampai dengan perubahan tersebut masih dapat ditoleransi agar usaha tetap layak. Pada penelitian ini ada dua variabel yang diasumsikan akan berpengaruh terhadap kelayakan usaha agrowisata, yaitu variabel dari sisi penerimaan adalah penurunan jumlah pengunjung dan variabel dari sisi pengeluaran adalah kenaikan gaji tenaga kerja tetap. Hasil analisis swicthing value dapat dilihat pada Tabel 4 di bawah ini.

\section{Tabel 4. Hasil Analisis Swicthing Value} Skenario I dan Skenario II

\begin{tabular}{lcc}
\hline \multicolumn{1}{c}{$\begin{array}{c}\text { Analisis } \\
\text { Switching Value }\end{array}$} & Skenario I & Skenario II \\
\hline $\begin{array}{l}\text { Penurunan jumlah } \\
\text { pengunjung }\end{array}$ & $47,35 \%$ & $66,56 \%$ \\
$\begin{array}{l}\text { Kenaikan gaji } \\
\text { tenaga kerja tetap }\end{array}$ & $304 \%$ & $577,3 \%$ \\
\hline
\end{tabular}

Berdasarkan hasil analisis switching value seperti yang terlihat pada Tabel 4 diketahui batas maksimal penurunan jumlah pengunjung agar usaha tetap layak pada skenario I adalah sebesar 47,35 \% dan pada skenario II adalah sebesar $66,56 \%$. Sementara batas maksimal kenaikan gaji tenaga kerja tetap agar usaha tetap layak pada skenario I adalah sebesar $304 \%$ dan pada skenario II adalah sebesar 577,3 \%. Jika perubahan pada kedua variabel melebihi angka tersebut akan membuat usaha yang dijalankan menjadi tidak layak. Selain itu hasil tersebut menunjukkan bahwa penurunan jumlah pengunjung lebih sensitif terhadap kelayakan usaha jika dibandingkan dengan kenaikan gaji tenaga kerja tetap, baik pada skenario I maupun skenario II.

Penurunan jumlah pengunjung dapat terjadi karena beberapa kemungkinan. Diantaranya adalah banyaknya pesaing di bidang pariwisata yang menyebabkan pangsa pasar usaha agrowisata di Kabupaten Rembang menjadi rendah. Kemudian bisa disebabkan oleh strategi pemasaran yang kurang tepat, sehingga kurang mampu menarik minat wisatawan untuk berkunjung. Sementara itu kenaikan gaji tenaga kerja tetap biasanya harus mengikuti acuan Upah Minimum Regional (UMR) yang berlaku,

\section{SIMPULAN DAN SARAN}

\section{SIMPULAN}

Dari penelitian tersebut dapat disimpulkan berdasarkan pada hasil analisis aspek non finansial bahwa usaha agrowisata di Kabupaten Rembang layak untuk dijalankan dengan syarat adanya peningkatan market share pada aspek pasar antara lain sebagai berikut :

1. Berdasarkan hasil analisis finansial, usaha agrowisata tanpa penambahan fasilitas rumah makan (skenario 1) dan dengan penambahan fasilitas rumah makan (skenario II) layak untuk dijalankan menurut kriteria investasi NPV, Net B/C, IRR, dan PP. Hasil analisis kelayakan finansial pada usaha agrowisata dengan penambahan fasilitas rumah makan mempunyai performa finansial yang lebih baik dibanding usaha agrowisata tanpa dilengkapi fasilitas rumah makan.

2. Berdasarkan analisis swicthing value pada usaha agrowisata tanpa penambahan fasilitas rumah makan (skenario I) dan usaha agrowisata dengan penambahan fasilitas rumah makan (skenario II) didapatkan hasil yang 
sama bahwa usaha agrowisata lebih sensitif terhadap penurunan jumlah pengunjung jika dibandingkan dengan kenaikan gaji tenaga kerja tetap.

\section{SARAN}

Berdasarkan simpulan dan hasil penelitian di atas, maka ada beberapa saran terhadap usaha agrowisata di Kabupaten Rembang yaitu :

1. Pemerintah Kabupaten Rembang perlu untuk mendorong pengembangan usaha agrowisata, pasalnya Kabupaten Rembang mempunyai banyak komoditas holtikultura unggulan seperti durian, mangga, pisang, dan duku. Usaha agrowisata mampu memberikan nilai edukasi dan pengalaman tentang dunia pertanian, sehingga diharapkan masyarakat ikut mendukung pengembangan usaha agrowisata di Kabupaten Rembang.

2. Pelaku usaha agrowisata di Kabupaten Rembang perlu memerhatikan jumlah wisatawan yang berkunjung, karena penurunan jumlah wisatawan sangat memengaruhi kinerja keuangan usaha agriwisata. Oleh karena itu dibutuhkan beberapa strategi untuk mempertahankan atau bahkan mampu meningkatkan minat wisatawan untuk berkunjung.

3. Strategi yang dapat dilakukan antara lain adalah melalui kegiatan promosi yang efektif dengan cara melakukan kunjungan dan kerjasama ke sekolah-sekolah mulai dari PAUD, TK, dan SD, serta meningkatkan promosi melalui media sosial dan bekerja sama dengan komunitas-komunitas yang ada di daerah Rembang. Strategi yang selanjutnya adalah memberikan tawaran paroduk dalam bentuk paket wisata untuk mampu menarik minat wisatawan.

4. Bagi para peneliti di Kabupaten Rembang, khususnya di bidang pariwisata diharapkan adanya penelitian tentang agrowisata dengan skenario usaha yang berbeda ataupun topik yang berbeda

\section{DAFTAR PUSTAKA}

Arifin H S 2001. Peran Arsitek Lanskap dalam Perencanaan dan Pengembangan Wisata
Agro di Indonesia. Proyek Koordinasi Peningkatan Ketahanan Pangan

[BPS] Badan Pusat Statistik Kabupaten Rembang. 2019. Kabupaten Rembang Dalam Angka 2018 [internet]. [Diunduh pada 3 september 2019]. Tersedia https://rembangkab.bps.go.id

[BPS] Badan Pusat Statistik Kabupaten Rembang. 2019. Rencana Pembangunan Jangka Panjang Daerah Kabupaten Rembang 20052025 [internet]. [Diunduh pada 16 Desember 2019]. Tersedia https://rembangkab.bps.go.id

[BPS] Badan Pusat Statistik Kabupaten Rembang. 2019. Rata-rata Pengeluaran per Kapita Sebulan Menurut Kelompok Makanan dan Kelompok Pengeluaran (Rupiah) tahun 2019. [Diunduh pada 30 Januari 2020]. Tersedia di https://rembangkab.bps.go.id

[BPS] Badan Pusat Statistik Kabupaten Rembang. 2018. Statistik Holtikultura Kabupaten Rembang 2018 [internet]. [Diunduh pada 16 Oktober 2020]. Tersedia di https://rembangkab.bps.go.id

Destriani R P. 2013. Analisis kelayakan pengembangan usaha budidaya buah naga (Hylocereus sp.) di Desa Rombasan Kecamatan Pragaan Kabupaten Sumenep Jawa Timur [skripsi]. Bogor: Fakultas Ekonomi dan Manajemen, Institut Pertanian Bogor.

Dewi T A dan Farmayanti N. 2011. Analisis Kelayakan Pengembangan Usaha Ternak Kambing Perah (Studi Kasus: Peternakan PrimaFit, Kecamatan Ciampea, Kabupaten Bogor). Forum Agribisnis Vol 1 (1): 95-111

Dinas Kebudayaan dan Pariwisata Kabupaten Rembang. 2019. Wisatawan yang Berkunjung ke Kabupaten Rembang Tahun 2015-2019

Dinas Kebudayaan dan Pariwisata Kabupaten Rembang. 2019. Pertumbuhan Obyek Wisata di Kabupaten Rembang Tahun 2015-2019

Dinas Kebudayaan dan Pariwisata Provinsi Jawa Tengah. Jumlah Wisatawan Domestik dan Mancanegara di Jawa Tengah tahun 20142018 [internet]. [Diunduh 30 Juni 2020]. Tersedia di jateng.bps.go.id 
[KEMENPAR] Kementrian Pariwisata. 2019. Kontribusi Sektor Pariwisata terhadap PDB [internet]. [Diakses pada 4 Juli 2020]. Tersedia pada: https://lokadata. beritagar.id/chart/preview/ kontribusi pariwisata -terhadap-pdb-2010-20191582001327

[KEMENPAR] Kementrian Pariwisata. 2019. Jumlah Wisatawan Domestik dan Mancanegara yang Berkunjung ke Indonesia 2015-2018 [internet].[Diakses pada 28 Januari 2020]. Tersedia di bps.go.id

Malkanthi S H. dan Routry J K. 2011. Potential For Agritourism Development: Evidence From Sri Langka. Journal of Agricultural Sciences. Vol 9 (1): 45-58

Nabila W F dan Nurmalina R. 2019. Analisis Kelayakan Usaha Minyak Serai Wangi pada Kondisi Risiko (Studi Kasus PT. Musim Panen Harmonis). Forum Agribisnis Vol 9 (2): 143159 https://doi.org/10.29244/fagb.9.2.143159

Nisa C, Winandi R, dan Tinaprilla N. 2014. Analisis Kelayakan Investasi Penggemukan Sapi Potong (Kasus: PT Catur Mitra Taruma, Kabupaten Bogor). Forum Agribisnis. Vol 4 (1): $35-52$ https://doi.org/10.29244/fagb.4.1.35-52

Nurmalina R, Sarianti T, Karyadi A. 2014. Studi Kelayakan Bisnis. Bogor (ID): IPB Press

Nurmalina R dan Sarianti T. 2016. Analisis Kelayakan Agribisnis. Banten. Universitas Terbuka

Ramadhanty et al. 2020. Analisis Kelayakan Usaha Budidaya Selada Krop di CV. Cantigi Desa Cikandang Kecamatan Cikajang Kabupaten Garut. Forum Agribisnis. Vol 10 (1): 27-35 https://doi.org/10.29244/fagb.10.1.27-35

Sasongko et al. 2019. Strategi Pengembangan Kawasan Wisata Kuliner di Sepanjang Koridor Jalan Soekarno-Hatta, Kota Malang. Fakultas Tenik Sipil dan Prencanaan, Institut Teknologi Nasional Malang

Sucipto A. 2011. Studi Kelayakan Bisnis. Malang: UIN Maliki Press
Sumantri B dan Farianti A. 2011. Kelayakan Pengembangan Usaha Integrasi Padi dengan Sapi Potong Pada Kondisi Risiko di Kelompok Tani Dewi Sri. Forum Agribisnis. Vol 1 (2):167-182 https://doi.org/10.29244/fagb.1.2.167-182

Syaifullah M H. 2018. Studi Kelayakan Usaha Pengembangan Agrowisata Jambu Madu Beji Farm (Kota Batu, Jawa Timur).[skripsi]. Bogor. Fakultas Ekonomi dan Manajemen, Institut Pertanian Bogor 


\section{LAMPIRAN}

\section{Lampiran 1. Asumsi Dasar}

Asumsi dasar yang digunakan dalam penelitian ini adalah sebagai berikut:

1. Usaha agrowisata di Kabupaten Rembang merupakan usaha milik perorangan

2. Modal usaha yang digunakan pada skenario I dan skenario II diasumsikan sepenuhnya dari modal sendiri

3. Jumlah wisatawan pada skenario I dan skenario II diasumsikan sama

4. Umur usaha adalah 15 tahun, hal ini didasarkan pada umur dari tanaman buah naga

5. Luas lahan yang digunakan untuk usaha agrowisata di Kabupaten Rembang seluas 0.88 Ha dan ditanami buah naga dengan jumlah 647 pohon

6. Tingkat suku bunga diskonto yang digunakan dalam penelitian ini adalah suku bunga Bank Mandiri bulan Februari 2020 sebesar $4.5 \%$

7. Produk barang yang dihasilkan oleh usaha agrowisata di Kabupaten Rembang adalah buah naga, dengan harga jual Rp 15 000/ kg,- (diasumsikan tetap)

8. Produk jasa yang dihasilkan oleh usaha agrowisata di Kabupaten Rembang adalah jasa edukasi, yaitu edukasi kelinci, tanam padi, tanam sayur, tanam buah naga, dan mewarnai. Berikut merupakan harga harga beberapa kategori paket wisata:

- Tiket masuk biasa : : Rp 5 000/ orang

- Edukasi kelinci : : Rp $5000 /$ orang

- Tanam padi : :Rp $5000 /$ orang

- Tanam sayuran : Rp $5000 /$ orang

- Tanam buah naga dalam polybag : Rp 10 000/ orang

- Mewarnai di alam terbuka : :Rp $8000 /$ orang

9. Penerimaan pada skenario 1 untuk tahun 1 dan 2 diambil dari referensi selama usaha berjalan, sedangkan pada tahun ketiga didasarkan pada target yang ingin dicapai. Semetara mulai tahun ke4 hingga ke-15 diasumsikan naik sebesar $10 \%$ dari tahun sebelumnya. Hal ini berdasarkan minat masyarakat akan kebutuhan pariwisata di Kabupaten Rembang yang terus meningkat.

10. Menu yang tersedia dihasilkan dari hasil survei kepada para wisatawan di Kabupaten Rembang, yaitu sebagai berikut:

- Makanan berat:

$\begin{array}{ll}\text { Bakso } & : \operatorname{Rp} 15000 / \text { porsi } \\ \text { Mie ayam } & : \text { Rp } 800 / \text { porsi } \\ \text { Nasi pecel } & : \text { Rp } 8000 / \text { porsi } \\ \text { Nasi soto } & : \operatorname{Rp~} 8000 / \text { porsi }\end{array}$

Ayam goreng dan nasi : Rp 10 000/ porsi

- Minuman:

Es kelapa muda : Rp 15 000/ cup

Es teh : :Rp $3000 /$ cup

Es jeruk : :Rp $5000 /$ cup

Jus buah naga : Rp 7 000/ cup

11. Nilai penjualan produk rumah makan (penerimaan yang dihasilkan dari jumlah penjualan masingmasing varian menu dikalikan dengan harga jualnya) dihasilkan dari survey terkait kegiatan konsumsi wisatawan di tempat wisata, sehingga diperoleh hasil $97.4 \%$ melakukan kegiatan konsumsi makanan dan $93.6 \%$ melakukan kegiatan konsumsi minuman. Sedangkan untuk jumlah penjualan per item menu diasumsikan sama. 


\section{Lampiran 2. Cashflow Skenario I dan Skenario II}

\section{Cashflow Skenario I Tahun 0 - 5}

\begin{tabular}{|c|c|c|c|c|c|c|c|}
\hline \multirow{3}{*}{ No } & \multirow{3}{*}{ Uraian } & \multicolumn{6}{|c|}{ Skenario I } \\
\hline & & \multicolumn{6}{|c|}{ Tahun } \\
\hline & & $\mathbf{0}$ & 1 & 2 & 3 & 4 & 5 \\
\hline \multirow[t]{6}{*}{1} & INFLOW & & & & & & \\
\hline & a. Penjualan Buah naga & & $67,935,000$ & $97,050,000$ & $97,050,000$ & $126,165,000$ & $145,575,000$ \\
\hline & b. Pendapatan Agrowisata & & $237,162,000$ & $198,925,000$ & $339,050,000$ & $372,955,000$ & $410,247,000$ \\
\hline & c. Penerimaan Rumah Maka & & & & & & \\
\hline & c. Nilai sisa & & & & & & \\
\hline & Total Inflow & & $305,097,000$ & $295,975,000$ & $436,100,000$ & $499,120,000$ & $555,822,000$ \\
\hline \multirow[t]{10}{*}{2} & OUTFLOW & & & & & & \\
\hline & Biaya Investasi & & & & & & \\
\hline & Total Biaya Investasi & $3,855,654,000$ & 0 & 0 & 0 & $1,291,000$ & 650,000 \\
\hline & $\begin{array}{l}\text { Biaya Operasional } \\
\text { a. Biaya Variabel }\end{array}$ & & & & & & \\
\hline & $\begin{array}{l}\text { Total biaya Variabel } \\
\text { b. Biaya Tetap }\end{array}$ & $38,820,000$ & $22,964,000$ & $23,431,000$ & $39,696,000$ & $42,441,000$ & $45,458,000$ \\
\hline & Total Biaya Tetap & & $159,000,000$ & $159,000,000$ & $159,000,000$ & $159,000,000$ & $159,000,000$ \\
\hline & c. Biaya Pajak PPn & & 494,141 & 446,196 & $1,065,496$ & $1,366,871$ & $1,635,296$ \\
\hline & d. Biaya Lain-lain & & & & & & \\
\hline & Total Biaya Lain-lain & $5,748,000$ & 48,000 & 48,000 & 48,000 & 48,000 & 48,000 \\
\hline & Total Outflow & $3,900,222,000$ & $182,506,141$ & $182,925,196$ & $199,809,496$ & $204,146,871$ & $206,791,296$ \\
\hline 3 & Net Benefit & $(3,900,222,000)$ & $122,590,859$ & $113,049,804$ & $236,290,504$ & $294,973,129$ & $349,030,704$ \\
\hline 4 & Discount Factor $(\mathrm{i}=4,5 \%)$ & 1 & 0.917431193 & 0.841679993 & 0.77218348 & 0.708425211 & 0.649931386 \\
\hline 5 & PV Benefit (i=4,5\%) & $(3,900,222,000)$ & $112,468,678$ & $95,151,758$ & $182,459,624$ & $208,966,401$ & $226,846,009$ \\
\hline 6 & NPV & $2,592,763,900$ & & & & & \\
\hline 7 & Net B/C & 1,66 & & & & & \\
\hline 8 & IRR & $9,7 \%$ & & & & & \\
\hline \multirow[t]{2}{*}{9} & Payback Period & 10 Tahun 9 & & & & & \\
\hline & & Bulan & & & & & \\
\hline
\end{tabular}

\section{Cashflow Skenario II Tahun 0 - 5}

\begin{tabular}{|c|c|c|c|c|c|c|c|}
\hline \multirow{3}{*}{ No } & \multirow{3}{*}{ Uraian } & \multicolumn{6}{|c|}{ Skenario II } \\
\hline & & \multicolumn{6}{|c|}{ Tahun } \\
\hline & & $\mathbf{0}$ & 1 & 2 & 3 & 4 & 5 \\
\hline \multirow[t]{6}{*}{1} & INFLOW & & & & & & \\
\hline & a. Penjualan Buah naga & & $67,935,000$ & $97,050,000$ & $97,050,000$ & $126,165,000$ & $145,575,000$ \\
\hline & b. Pendapatan Agrowisata & & $237,162,000$ & $198,925,000$ & $339,050,000$ & $372,955,000$ & $410,247,000$ \\
\hline & c. Penerimaan Rumah Makan & & $619,942,600$ & $499,715,400$ & $811,124,200$ & $892,240,000$ & $981,461,600$ \\
\hline & c. Nilai sisa & & & & & & \\
\hline & Total Inflow & & $925,039,600$ & $795,690,400$ & $1,247,224,200$ & $1,391,360,000$ & $1,537,283,600$ \\
\hline \multirow[t]{10}{*}{2} & OUTFLOW & & & & & & \\
\hline & Biaya Investasi & & & & & & \\
\hline & Total Biaya Investasi & $3,958,708,000$ & 500,000 & 500,000 & $1,510,000$ & $3,160,000$ & $1,890,000$ \\
\hline & $\begin{array}{l}\text { Biaya Operasional } \\
\text { a. Biaya Variabel }\end{array}$ & & & & & & \\
\hline & $\begin{array}{l}\text { Total biaya Variabel } \\
\text { b. Biaya Tetap }\end{array}$ & $38,820,000$ & $394,494,500$ & $322,906,100$ & $525,801,000$ & $577,158,600$ & $633,645,800$ \\
\hline & Total Biaya Tetap & & $223,200,000$ & $223,200,000$ & $223,200,000$ & $223,200,000$ & $223,200,000$ \\
\hline & c. Biaya Pajak PPn & & $1,705,633$ & $1,350,031$ & $2,766,251$ & $3,275,214$ & $3,771,968$ \\
\hline & d. Biaya Lain-lain & & & & & & \\
\hline & Total Biaya Lain-lain & $5,748,000$ & 48,000 & 48,000 & 48,000 & 48,000 & 48,000 \\
\hline & Total Outflow & $4,003,276,000$ & $619,948,133$ & $548,004,131$ & $753,325,251$ & $806,841,814$ & $862,555,768$ \\
\hline 3 & Net Benefit & $(4,003,276,000)$ & $305,091,467$ & $247,686,269$ & $493,898,949$ & $584,518,186$ & $674,727,832$ \\
\hline 4 & Discount Factor $(\mathrm{i}=4,5 \%)$ & 1 & 0.917431193 & 0.841679993 & 0.77218348 & 0.708425211 & 0.649931386 \\
\hline 5 & PV Benefit (i=4,5\%) & $(4,003,276,000)$ & $279,900,429$ & $208,472,577$ & $381,380,609$ & $414,087,419$ & $438,526,795$ \\
\hline 6 & NPV & 7.259.729.779 & & & & & \\
\hline 7 & Net B/C & 2,8 & & & & & \\
\hline 8 & IRR & $17,2 \%$ & & & & & \\
\hline 9 & Payback Period & 7 tahun 2 bulan & & & & & \\
\hline
\end{tabular}


Cashflow Skenario I Tahun 6 - 11

\begin{tabular}{|c|c|c|c|c|c|c|c|}
\hline \multirow{3}{*}{ No } & \multirow{3}{*}{ Uraian } & \multicolumn{6}{|c|}{ Skenario I } \\
\hline & & \multicolumn{6}{|c|}{ Tahun } \\
\hline & & 6 & 7 & 8 & 9 & 10 & 11 \\
\hline \multirow{4}{*}{1} & INFLOW & & & & & & \\
\hline & a. Penjualan Buah naga & $145,575,000$ & $145,575,000$ & $145,575,000$ & $145,575,000$ & $145,575,000$ & $126,165,000$ \\
\hline & $\begin{array}{l}\text { b. Pendapatan Agrowisata } \\
\text { c. Penerimaan Rumah Makan } \\
\text { c. Nilai sisa }\end{array}$ & $451,286,000$ & $496,411,000$ & $546,047,000$ & $600,646,000$ & $660,713,000$ & $726,787,000$ \\
\hline & Total Inflow & $596,861,000$ & $641,986,000$ & $691,622,000$ & $746,221,000$ & $806,288,000$ & $852,952,000$ \\
\hline \multirow[t]{7}{*}{2} & $\begin{array}{l}\text { OUTFLOW } \\
\text { Biaya Investasi }\end{array}$ & & & & & & \\
\hline & $\begin{array}{l}\text { Total Biaya Investasi } \\
\text { Biaya Operasional } \\
\text { a. Biaya Variabel }\end{array}$ & $19,105,000$ & $1,291,000$ & 0 & $1,835,000$ & $1,291,000$ & $39,505,000$ \\
\hline & $\begin{array}{l}\text { Total biaya Variabel } \\
\text { b. Biaya Tetap }\end{array}$ & $48,785,000$ & $52,437,000$ & $56,454,000$ & $60,873,000$ & $65,736,000$ & $71,086,000$ \\
\hline & Total Biaya Tetap & $159,000,000$ & $159,000,000$ & $159,000,000$ & $159,000,000$ & $159,000,000$ & $159,000,000$ \\
\hline & $\begin{array}{l}\text { c. Biaya Pajak PPn } \\
\text { d. Biaya Lain-lain }\end{array}$ & $1,823,856$ & $2,031,221$ & $4,518,632$ & $5,020,432$ & $5,572,472$ & $5,985,612$ \\
\hline & Total Biaya Lain-lain & 48,000 & 48,000 & 48,000 & 48,000 & 48,000 & 48,000 \\
\hline & Total Outflow & $228,761,856$ & $214,807,221$ & $220,020,632$ & $226,776,432$ & $231,647,472$ & $275,624,612$ \\
\hline 3 & Net Benefit & $368,099,144$ & $427,178,779$ & $471,601,368$ & $519,444,568$ & $574,640,528$ & $577,327,388$ \\
\hline 4 & Discount Factor $(\mathrm{i}=4,5 \%)$ & 0.767895738 & 0.734828458 & 0.703185127 & 0.672904428 & 0.643927682 & 0.616198739 \\
\hline 5 & PV Benefit $(\mathrm{i}=4,5 \%)$ & $282,661,764$ & $313,903,123$ & $331,623,068$ & $349,536,550$ & $370,026,943$ & $355,748,408$ \\
\hline 6 & NPV & $2,592,763,900$ & & & & & \\
\hline 7 & Net B/C & 1,66 & & & & & \\
\hline 8 & IRR & $9,7 \%$ & & & & & \\
\hline 9 & Payback Period & 10 Tahun 9 Bulan & & & & & \\
\hline
\end{tabular}

Cashflow Skenario II Tahun 6 - 11

\begin{tabular}{|c|c|c|c|c|c|c|c|}
\hline \multirow{3}{*}{ No } & \multirow{3}{*}{ Uraian } & \multicolumn{6}{|c|}{ Skenario II } \\
\hline & & \multicolumn{6}{|c|}{ Tahun } \\
\hline & & 6 & 7 & 8 & 9 & 10 & 11 \\
\hline \multirow[t]{5}{*}{1} & INFLOW & & & & & & \\
\hline & a. Penjualan Buah naga & $145,575,000$ & $145,575,000$ & $145,575,000$ & $145,575,000$ & $145,575,000$ & $126,165,000$ \\
\hline & b. Pendapatan Agrowisata & $451,286,000$ & $496,411,000$ & $546,047,000$ & $600,646,000$ & $660,713,000$ & $726,787,000$ \\
\hline & $\begin{array}{l}\text { c. Penerimaan Rumah Makan } \\
\text { c. Nilai sisa }\end{array}$ & $1,079,620,400$ & $1,187,573,400$ & $1,306,339,400$ & $1,436,965,000$ & $1,580,660,800$ & $1,738,727,800$ \\
\hline & Total Inflow & $1,676,481,400$ & $1,829,559,400$ & $1,997,961,400$ & $2,183,186,000$ & $2,386,948,800$ & $2,591,679,800$ \\
\hline \multirow[t]{10}{*}{2} & OUTFLOW & & & & & & \\
\hline & Biaya Investasi & & & & & & \\
\hline & Total Biaya Investasi & $36,250,000$ & $3,160,000$ & 50,000 & $12,035,000$ & $3,160,000$ & $55,190,000$ \\
\hline & $\begin{array}{l}\text { Biaya Operasional } \\
\text { a. Biaya Variabel }\end{array}$ & & & & & & \\
\hline & $\begin{array}{l}\text { Total biaya Variabel } \\
\text { b. Biaya Tetap }\end{array}$ & $695,799,020$ & $764,147,322$ & $839,340,304$ & $922,042,805$ & $1,013,022,815$ & $1,113,101,707$ \\
\hline & Total Biaya Tetap & $223,200,000$ & $223,200,000$ & $223,200,000$ & $223,200,000$ & $223,200,000$ & $223,200,000$ \\
\hline & c. Biaya Pajak PPn & $4,211,731$ & $4,695,364$ & $10,454,795$ & $11,625,168$ & $12,912,692$ & $14,134,857$ \\
\hline & d. Biaya Lain-lain & & & & & & \\
\hline & Total Biaya Lain-lain & 48,000 & 48,000 & 48,000 & 48,000 & 48,000 & 48,000 \\
\hline & Total Outflow & $959,508,751$ & $995,250,686$ & $1,073,093,099$ & $1,168,950,973$ & $1,252,343,507$ & $1,405,674,564$ \\
\hline 3 & Net Benefit & $716,972,649$ & $834,308,714$ & $924,868,301$ & $1,014,235,027$ & $1,134,605,293$ & $1,186,005,236$ \\
\hline 4 & Discount Factor $(\mathrm{i}=4,5 \%)$ & 0.767895738 & 0.734828458 & 0.703185127 & 0.672904428 & 0.643927682 & 0.616198739 \\
\hline 5 & PV Benefit $(i=4,5 \%)$ & $550,560,241$ & $613,073,786$ & $650,353,634$ & $682,483,241$ & $730,603,756$ & $730,814,931$ \\
\hline 6 & NPV & 7.259.729.779 & & & & & \\
\hline 7 & Net B/C & 2,8 & & & & & \\
\hline 8 & IRR & $17,2 \%$ & & & & & \\
\hline 9 & Payback Period & 7 tahun 2 bulan & & & & & \\
\hline
\end{tabular}


Cashflow Skenario I Tahun 12 - 15

\begin{tabular}{|c|c|c|c|c|c|}
\hline \multirow{3}{*}{ No } & \multirow{3}{*}{ Uraian } & \multicolumn{4}{|c|}{ Skenario I } \\
\hline & & \multicolumn{4}{|c|}{ Tahun } \\
\hline & & 12 & 13 & 14 & 15 \\
\hline \multirow[t]{6}{*}{1} & INFLOW & & & & \\
\hline & a. Penjualan Buah naga & $126,165,000$ & $97,050,000$ & $97,050,000$ & $67,935,000$ \\
\hline & b. Pendapatan Agrowisata & $799,454,000$ & $879,461,000$ & $967,356,000$ & $1,064,086,000$ \\
\hline & c. Penerimaan Rumah Makan & & & & \\
\hline & c. Nilai sisa & & & & $3,559,260,625$ \\
\hline & Total Inflow & $925,619,000$ & $976,511,000$ & $1,064,406,000$ & $4,691,281,625$ \\
\hline \multirow[t]{10}{*}{2} & OUTFLOW & & & & \\
\hline & Biaya Investasi & & & & \\
\hline & Total Biaya Investasi & 0 & $1,941,000$ & 0 & 0 \\
\hline & $\begin{array}{l}\text { Biaya Operasional } \\
\text { a. Biaya Variabel }\end{array}$ & & & & \\
\hline & $\begin{array}{l}\text { Total biaya Variabel } \\
\text { b. Biaya Tetap }\end{array}$ & $76,967,000$ & $83,443,000$ & $90,563,000$ & $98,395,000$ \\
\hline & Total Biaya Tetap & $159,000,000$ & $159,000,000$ & $159,000,000$ & $159,000,000$ \\
\hline & c. Biaya Pajak PPn & $6,653,472$ & $7,097,632$ & $7,905,382$ & $8,503,212$ \\
\hline & d. Biaya Lain-lain & & & & \\
\hline & Total Biaya Lain-lain & 48,000 & 48,000 & 48,000 & 48,000 \\
\hline & Total Outflow & $242,668,472$ & $251,529,632$ & $257,516,382$ & $265,946,212$ \\
\hline 3 & Net Benefit & $682,950,528$ & $724,981,368$ & $806,889,618$ & $4,425,335,413$ \\
\hline 4 & Discount Factor $(\mathrm{i}=4,5 \%)$ & 0.589663865 & 0.564271641 & 0.539972862 & 0.516720442 \\
\hline 5 & PV Benefit (i=4,5\%) & $402,711,248$ & $409,086,426$ & $435,698,496$ & $2,286,661,271$ \\
\hline 6 & NPV & $2,592,763,900$ & & & \\
\hline 7 & Net B/C & 1,66 & & & \\
\hline 8 & IRR & $9,7 \%$ & & & \\
\hline 9 & Payback Period & 10 Tahun 9 Bulan & & & \\
\hline
\end{tabular}

\section{Cashflow Skenario II Tahun 12 - 15}

\begin{tabular}{|c|c|c|c|c|c|}
\hline \multirow{3}{*}{ No } & \multirow{3}{*}{ Uraian } & \multicolumn{4}{|c|}{ Skenario II } \\
\hline & & \multicolumn{4}{|c|}{ Tahun } \\
\hline & & 12 & 13 & 14 & 15 \\
\hline \multirow[t]{6}{*}{1} & INFLOW & & & & \\
\hline & a. Penjualan Buah naga & $126,165,000$ & $97,050,000$ & $97,050,000$ & $67,935,000$ \\
\hline & b. Pendapatan Agrowisata & $799,454,000$ & $879,461,000$ & $967,356,000$ & $1,064,086,000$ \\
\hline & c. Penerimaan Rumah Makan & $1,912,597,800$ & $2,104,010,400$ & $2,314,249,200$ & $2,545,667,800$ \\
\hline & c. Nilai sisa & & & & $3,561,225,625$ \\
\hline & Total Inflow & $2,838,216,800$ & $3,080,521,400$ & $3,378,655,200$ & $7,238,914,425$ \\
\hline \multirow[t]{10}{*}{2} & OUTFLOW & & & & \\
\hline & Biaya Investasi & & & & \\
\hline & Total Biaya Investasi & $1,510,000$ & $5,000,000$ & 50,000 & $1,510,000$ \\
\hline & $\begin{array}{l}\text { Biaya Operasional } \\
\text { a. Biaya Variabel }\end{array}$ & & & & \\
\hline & $\begin{array}{l}\text { Total biaya Variabel } \\
\text { b. Biaya Tetap }\end{array}$ & $1,223,182,567$ & $1,344,369,854$ & $1,477,487,559$ & $1,624,008,295$ \\
\hline & Total Biaya Tetap & $223,200,000$ & $223,200,000$ & $223,200,000$ & $223,200,000$ \\
\hline & c. Biaya Pajak PPn & $15,692,630$ & $17,116,509$ & $19,000,310$ & $20,782,605$ \\
\hline & d. Biaya Lain-lain & & & & \\
\hline & Total Biaya Lain-lain & 48,000 & 48,000 & 48,000 & 48,000 \\
\hline & Total Outflow & $1,463,633,197$ & $1,589,734,363$ & $1,719,785,869$ & $1,869,548,900$ \\
\hline 3 & Net Benefit & $1,374,583,603$ & $1,490,787,037$ & $1,658,869,331$ & $5,369,365,525$ \\
\hline 4 & Discount Factor $(\mathrm{i}=4,5 \%)$ & 0.589663865 & 0.564271641 & 0.539972862 & 0.516720442 \\
\hline 5 & PV Benefit (i=4,5\%) & $810,542,280$ & $841,208,848$ & $895,744,420$ & $2,774,460,927$ \\
\hline 6 & NPV & 7.259.729.779 & & & \\
\hline 7 & Net B/C & 2,8 & & & \\
\hline 8 & IRR & $17,2 \%$ & & & \\
\hline 9 & Payback Period & 7 tahun 2 bulan & & & \\
\hline
\end{tabular}


Lampiran 3. Biaya Investasi Skenario I

\begin{tabular}{|c|c|c|c|c|c|}
\hline No & Uraian & Jumlah & Satuan & Harga Satuan & Nilai \\
\hline 1 & Lahan & 8,800 & $\mathrm{~m} 2$ & 400,000 & $3,520,000,000$ \\
\hline 2 & Cagak(tiang buah naga) & 647 & Unit & 85,000 & $54,995,000$ \\
\hline 3 & Rumah Kelinci & 1 & Unit & $115,000,000$ & $115,000,000$ \\
\hline 4 & Bibit Buah Naga & 2,588 & Bibit & 6,000 & $15,528,000$ \\
\hline 5 & Pagar & 1 & Keliling & $20,000,000$ & $20,000,000$ \\
\hline 6 & Gazebo Besar & 1 & Buah & $8,000,000$ & $8,000,000$ \\
\hline 7 & Gazebo Kecil & 2 & Buah & $4,000,000$ & $8,000,000$ \\
\hline 8 & Taman & 1 & Paket & $25,000,000$ & $25,000,000$ \\
\hline 9 & Kanopi \& Gerbang & 1 & Unit & $7,000,000$ & $7,000,000$ \\
\hline 10 & Loket & 1 & Unit & $5,500,000$ & $5,500,000$ \\
\hline 11 & Sumur dan pengairan & 1 & Paket & $5,500,000$ & $5,500,000$ \\
\hline 12 & Toilet \& Shower & 1 & Paket & $15,000,000$ & $15,000,000$ \\
\hline 13 & Kandang Kelinci & 6 & Kandang & 350,000 & $2,100,000$ \\
\hline 14 & Kelinci & 80 & Ekor & 100,000 & $8,000,000$ \\
\hline 15 & Spot Foto Sarang burung & 1 & Unit & $2,500,000$ & $2,500,000$ \\
\hline 16 & Spot foto Kupu-kupu & 1 & Unit & $1,500,000$ & $1,500,000$ \\
\hline 17 & Spot foto doraemon & 1 & Unit & $2,750,000$ & $2,750,000$ \\
\hline 18 & Spot foto bintang & 1 & Unit & $1,000,000$ & $1,000,000$ \\
\hline 19 & Spot foto terowongan & 1 & Unit & 500,000 & 500,000 \\
\hline 20 & spot foto love & 1 & Unit & $1,000,000$ & $1,000,000$ \\
\hline 21 & Spot foto sepedah & 1 & Unit & 700,000 & 700,000 \\
\hline 22 & Taman Ban & 1 & Taman & $6,000,000$ & $6,000,000$ \\
\hline 23 & Plang Utama & 1 & Unit & $5,000,000$ & $5,000,000$ \\
\hline 24 & Penunjuk jalan & 1 & Paket & $2,000,000$ & $2,000,000$ \\
\hline 25 & Gazebo lingkaran & 2 & Unit & $2,000,000$ & $4,000,000$ \\
\hline 26 & Spot foto Bola & 1 & Paket & $1,000,000$ & $1,000,000$ \\
\hline 27 & Gudang & 1 & Unit & $3,000,000$ & $3,000,000$ \\
\hline 28 & Gawang & 2 & Unit & $1,500,000$ & $3,000,000$ \\
\hline 29 & Bunga dan tanaman hias & 1 & paket & $6,000,000$ & $6,000,000$ \\
\hline 30 & Gunting tanaman & 5 & unit & 30,000 & 150,000 \\
\hline 31 & Timbangan buah & 2 & unit & 125,000 & 250,000 \\
\hline 32 & Cangkul & 5 & unit & 100,000 & 500,000 \\
\hline 33 & Keranjang buah & 15 & unit & 35,000 & 525,000 \\
\hline 34 & Gerobak dorong & 1 & unit & 585,000 & 585,000 \\
\hline 35 & Mesin Pemotong Rumput & 1 & unit & $1,000,000$ & $1,000,000$ \\
\hline 36 & Caping & 15 & unit & 13,000 & 195,000 \\
\hline 37 & Alat penyemprot hama & 1 & unit & 185,000 & 185,000 \\
\hline 38 & Lampu & 10 & unit & 30,000 & 300,000 \\
\hline 39 & Tandon air & 1 & unit & $1,400,000$ & $1,400,000$ \\
\hline \multirow[t]{2}{*}{40} & Alat kebersihan & 1 & set & 991,000 & 991,000 \\
\hline & & & & Total & $3,855,654,000$ \\
\hline
\end{tabular}


Lampiran 4. Biaya Investasi Tambahan Skenario II

\begin{tabular}{|c|c|c|c|c|c|}
\hline No & Uraian & Jumlah & Satuan & Harga Satuan & Nilai \\
\hline 1 & Bangunan & 75 & $\mathrm{~m} 2$ & $75,000,000$ & $\begin{array}{l}75,000,000 \\
75,000,000\end{array}$ \\
\hline \multirow[t]{18}{*}{2} & Peralatan Dapur & & & & \\
\hline & Freezer $105 \mathrm{~L}$ & 1 & Unit & $2,000,000$ & $2,000,000$ \\
\hline & Kulkas & 1 & Unit & $2,500,000$ & $2,500,000$ \\
\hline & Rice cooker besar & 1 & Unit & $1,000,000$ & $1,000,000$ \\
\hline & Kompor gas 2 tungku & 1 & Unit & 300,000 & 300,000 \\
\hline & Kompor gas 1 tungku & 1 & Unit & 120,000 & 120,000 \\
\hline & Tabung gas & 4 & Unit & 100,000 & 400,000 \\
\hline & Galon & 4 & Unit & 35,000 & 140,000 \\
\hline & Gerobak bakso dan mie ayam & 1 & Unit & $3,000,000$ & $3,000,000$ \\
\hline & Panci & 2 & Unit & 200,000 & 400,000 \\
\hline & Wajan & 2 & Unit & 120,000 & 240,000 \\
\hline & Spatula & 2 & Set & 100,000 & 200,000 \\
\hline & Baskom & 5 & Unit & 10,000 & 50,000 \\
\hline & Termos & 2 & Unit & 65,000 & 130,000 \\
\hline & Teko & 2 & Unit & 70,000 & 140,000 \\
\hline & Ice bucket $30 \mathrm{~L}$ & 1 & Unit & 225,000 & 225,000 \\
\hline & Pisau & 1 & Set & 150,000 & 150,000 \\
\hline & Serbet & 5 & Unit & 10,000 & $\begin{array}{r}50,000 \\
11045,000\end{array}$ \\
\hline \multirow[t]{11}{*}{3} & Peralatan Makan & & & & \\
\hline & Piring & 50 & Buah & 15,000 & 750,000 \\
\hline & Mangkok & 50 & Buah & 15,000 & 750,000 \\
\hline & Sendok makan & 4 & Lusin & 25,000 & 100,000 \\
\hline & Sendok teh & 4 & Lusin & 25,000 & 100,000 \\
\hline & Sendok jus & 40 & Buah & 1,000 & 40,000 \\
\hline & Garpu & 4 & Lusin & 25,000 & 100,000 \\
\hline & Gelas cangkir & 40 & Buah & 8,000 & 320,000 \\
\hline & Gelas teh & 40 & Buah & 10,000 & 400,000 \\
\hline & Gelas jus & 40 & Buah & 10,000 & 400,000 \\
\hline & & & & & $2,960,000$ \\
\hline \multirow[t]{17}{*}{4} & Peralatan lainnya & & & & \\
\hline & Meja & 8 & Unit & 300,000 & $2,400,000$ \\
\hline & Kursi & 35 & Unit & 100,000 & $3,500,000$ \\
\hline & Meja kasir & 1 & Unit & $1,000,000$ & $1,000,000$ \\
\hline & Meja saji & 1 & Unit & $1,500,000$ & $1,500,000$ \\
\hline & Meja dapur & 1 & Unit & $1,500,000$ & $1,500,000$ \\
\hline & Rak piring gelas dan mangkok & 2 & Unit & 150,000 & 300,000 \\
\hline & Lemari simpan & 1 & Unit & 500,000 & 500,000 \\
\hline & Tempat tisu & 8 & Unit & 30,000 & 240,000 \\
\hline & Tempat sendok dan garpu & 8 & Unit & 25,000 & 200,000 \\
\hline & Tempat saus dan kecap & 16 & Unit & 10,000 & 160,000 \\
\hline & Tempat sambal & 8 & Unit & 15,000 & 120,000 \\
\hline & Pemeras jeruk & 2 & Unit & 160,000 & 320,000 \\
\hline & Kipas angin & 3 & Unit & $1,000,000$ & $3,000,000$ \\
\hline & Keset & 3 & Unit & 100,000 & 300,000 \\
\hline & & & & & $15,040,000$ \\
\hline & & & & Total & $104,045,000$ \\
\hline
\end{tabular}

